\title{
A novel antiulcerogenic stable radical prevents gastric mucosal lesions in rats
}

\author{
D Rachmilewitz, F Karmeli, E Okon, A Samuni
}

\begin{abstract}
The pathogenesis of gastric mucosal injury is still poorly understood. Recent reports implicate redox active metals and reactive oxygen species as mediators of gastric damage induced by ethanol or non-steroidal anti-inflammatory drugs. Attempts were made therefore to prevent gastric injury using chelators and the antioxidant enzymes catalase and superoxide dismutase. These attempts, at best, would only detoxify extracellular reactive species, such as those produced by activated circulating granulocytes and macrophages. This study utilises another strategy by pre-emption of both intra and extracellular reactive species using radical-radical annihilation reactions and by detoxifying redox active transition metals. Nitroxide, stable free radicals were shown to enter mucous cells, protect against the ethanol induced damage, and prevent gastric lesions induced by aspirin, indomethacin, $25 \% \mathrm{NaCl}$, or $0.6 \mathrm{~N} \mathrm{HCl}$. These findings confirm that gastric mucosal damage from the above agents is mediated by free radicals and, moreover, introduce a prototypical agent within a potential new class of gastric ulcer preventing drugs.

(Gut 1994; 35: 1181-1188)
\end{abstract}

Oxygen derived radicals and non-radical species have been previously implicated in the pathogenesis of gastric ulceration induced by ethanol.1-2 Reactive oxygen species have been assumed to be mediators of acute gastric damage induced also by non-steroidal anti-inflammatory drugs (NSAIDs) such as indomethacin and aspirin. ${ }^{1-6}$ Previous attempts to attenuate gastric damage, therefore, included pre-treatment with catalase and superoxide dismutase to detoxify presumed reactive oxygen species. ${ }^{1-2}$ 6-7 In addition, chelating agents have been used to sequester redox active transition metals and prevent them from aggravating the damage. Protective effects of catalase and superoxide dismutase, previously seen, are anticipated if extracellular reactive oxygen species generated by circulating leucocytes predominantly contribute to the damage. The use of reagents, however, which do not enter the cell limits this approach to extracellular reactive species.

If radicals are instrumental in mediating biological damage, their rapid removal should provide protection. Reactions of free radical with diamagnetic molecules, however, give rise to secondary radicals, whereas radical-radical reactions are rapid and often result in stable non-toxic species. Such a strategy has been previously used with nitroxides to protect cells, ${ }^{8}$ organs, ${ }^{9}$ and whole animals ${ }^{10}$ against diverse insults. Nitroxides are cell permeable, comparatively non-toxic ${ }^{11}$ stable radicals, which are widely used as biophysical probes for monitoring membrane state, cellular $\mathrm{pH}$, and oxygen concentration, ${ }^{12-14}$ intracellular redox reactions, ${ }^{15}$ or as contrast agents for nuclear magnetic resonance imaging (MRI). ${ }^{16}$ Being capable of undergoing one electron redox reactions, 5-membered ring nitroxides such as 2-ethyl-2,5,5-trimethyl-3-oxazolidinoxyl, have been found to catalytically dismutase superoxide radicals:

$$
\begin{aligned}
& \underbrace{X^{-}}_{X^{\mathrm{N}-\mathrm{O}}+\mathrm{O}_{2}^{-}+\mathrm{H}^{+}} \rightleftharpoons \underbrace{X^{-}}_{\mathrm{O}^{\mathrm{N}-\mathrm{OH}}+\mathrm{O}_{2}[1]} \\
& \underbrace{X^{-}}_{X^{\mathrm{N}-\mathrm{OH}}+\mathrm{O}_{2}^{-}+\mathrm{H}^{+}} \rightarrow \underbrace{X^{-}}_{x^{\mathrm{N}-\mathrm{O}}+\mathrm{H}_{2} \mathrm{O}_{2}[2]}
\end{aligned}
$$

yielding $\mathrm{H}_{2} \mathrm{O}_{2}$ and molecular oxygen. Previous studies showed that nitroxides prevent lipid peroxidation ${ }^{17}$ and also protect cells by selectively detoxifying other free radicals. Studies using bacterial and cultured mammalian cells showed that nitroxides provide cytoprotection from toxicity induced by $\mathrm{H}_{2} \mathrm{O}_{2}, 818-19$-butyl hydroperoxide (t-BuOOH), tumour necrosis factor, ${ }^{20}$ mitomycin $c,{ }^{21}$ and ionising radiation. ${ }^{22}$

This study was undertaken in the light of the clinical challenge to prevent gastric mucosal injury and to gain better understanding of the pathogenesis of mucosal damage, this gastric mucosal damage has been induced in rats by ethanol, indomethacin, aspirin, $25 \% \mathrm{NaCl}$, and $0.6 \mathrm{~N} \mathrm{HCl}$ while the effect of 4-hydroxy2,2,6,6-tetramethylpiperidine-1-oxyl (TEMPOL) on the induction of gastric mucosal injury was investigated. The results show effective protection by TEMPOL against gastric mucosal injury induced by ethanol and non-steroidal anti-inflammatory drugs. This protection also provided direct evidence that free radicals mediate gastric mucosal damage.

\section{Methods}

CHEMICALS

Diethylenetriaminopentaacetic acid (DTPA), and 4-hydroxy-2,2,6,6-tetramethylpiperidine1-oxyl (TEMPOL), were purchased from
Dr A Samuni, Department of Molecular Biology, Hebrew University - Haddass Jerusalem 91120 , Israel.

Accepted for publication 21 December 1993 
Aldrich Chemicals. Fatty acid free bovine serum albumin, indomethacin, superoxide dismutase ferricytochrome $\mathrm{c}$ were obtained from Sigma Laboratories, Israel; aspirin (Aspegic, Lab Egic, Amily, France); ranitidine (Zantac, Glaxo, UK), leukotriene $\mathrm{B}_{4}$ and leukotriene $\mathrm{C}_{4}$ radioimmunoassay (Amersham, England). Mn(III)-desferrioxamine 1:1 chelate (Mn-DF) has been prepared by dissolving an excess of $\mathrm{MnO}_{2}$ in $\mathrm{DF}$ overnight, followed by centrifugation to remove unreacted $\mathrm{MnO}_{2}$, as previously described. ${ }^{23-24}$ Tri(oxalato) chromiate(III) $\mathrm{K}_{3}\left[\mathrm{Cr}\left(\mathrm{C}_{2} \mathrm{O}_{4}\right)_{3}\right] \cdot 3 \mathrm{H}_{2} \mathrm{O}(\mathrm{CrOx})$ was prepared as previously described. ${ }^{25}$

\section{ELECTRON PARAMAGNETIC RESONANCE (EPR) MEASUREMENTS}

Liquid samples - a volume of $100 \mathrm{ml}$ was drawn into a gas permeable, Teflon capillary of $0.8 \mathrm{~mm}$ inner diameter. The capillary was inserted into a quartz tube open at both ends and then placed within the EPR cavity.

Tissue samples - a gastric mucosa sample of $10-40 \mathrm{mg}$ wet weight was excised from the rat stomach immediately after death and placed in a special groove of a standard quartz made tissue cuvette. During the experiment, the sample within the spectrometer cavity was flushed with either air or $\mathrm{N}_{2}$, without disturbing the sample, and the EPR spectra were recorded on a Varian E9 $\mathrm{X}$-band spectrometer, operating at $9.45 \mathrm{GHz}$, $100 \mathrm{kHz}$ modulation frequency, $1 \mathrm{G}$ modulation amplitude, and 10-20 $\mathrm{mW}$ microwave power. The concentrations of the nitroxide in the samples studied were quantitated using a TEMPOL solution of a known concentration as a calibration standard. For the determination of the total concentration of nitroxide + reduced nitroxide, ferricyanide was used to oxidise the hydroxylamine.

\section{ENZYME PREPARATIONS}

Catalase (EC 1.11.1.6) was purchased from Sigma (10 $\mathrm{U} / \mu \mathrm{g})$ and from Boehringer Biochemicals $(65 \mathrm{U} / \mu \mathrm{g})$. Superoxide dismutase (EC. 1.15.1.1) was obtained from Sigma. The superoxide dismutase activity was assayed using hypoxanthine/xanthine oxidase as a generator of superoxide in the presence of $100 \mu \mathrm{M}$ ferricytochrome $\mathrm{c}$ and after its superoxide dismutase inhibitable reduction, using a Uvikon dual beam spectrophotometer. ${ }^{26}$ Both sample and reference cuvettes contained $130 \mathrm{U} / \mathrm{ml}$ catalase to remove $\mathrm{H}_{2} \mathrm{O}_{2}$. The reference cuvette contained an excess of superoxide dismutase, the reaction was started by adding $0.01 \mathrm{U} / \mathrm{ml}$ XO to both cuvettes. The initial rates of superoxide dismutase increase, in the absence (V) and the presence (v) of various amounts of superoxide dismutase were spectrophotometrically followed at $550 \mathrm{~nm}$ $\left(\epsilon^{550}=21 \mathrm{mM}^{-1} \mathrm{~cm}^{-1}\right)$. The superoxide dismutase activity was evaluated from the plots of $\mathrm{V} / \mathrm{v}$ dependence on the amount of superoxide dismutase added. Boiling the enzyme was not enough for the preparation of inactive-superoxide dismutase. Instead, the enzyme was incubated overnight with $10 \mathrm{mM}$ $\mathrm{H}_{2} \mathrm{O}_{2}$ at $\mathrm{pH} 10$, followed with dialysis against phosphate buffer pH 7 containing catalase. Subsequently the residual activity was determined as described above and was found to be less then $3 \%$.

\section{ANIMALS AND EXPERIMENT DESIGN}

Male rats (Sprague-Dawley strain), weighing $150-200 \mathrm{~g}$ were fasted overnight and permitted free access to water. To study the effect of TEMPOL, rats were treated intragastrically with 1-100 $\mathrm{mg}$ of TEMPOL/kg bw. Unless otherwise stated, the standard protocol included intragastric treatment with TEMPOL $0.1 \mathrm{~g} / \mathrm{kg}$ bw five minutes before induction of damage by intragastric administration of $1 \mathrm{ml}$ $96 \%$ ethanol. Control animals received equal volumes of saline before intragastric administration of ethanol. Another control group was treated intragastrically with only $0.9 \% \mathrm{NaCl}$. To assess the damage 10 minutes after ethanol administration, rats were killed by cervical dislocation; the stomach was removed and washed with ice cold $0 \cdot 15 \mathrm{M} \mathrm{NaCl}$, and the extent of haemorrhagic erosions in the glandular mucosa was assessed blindly by measuring the area of the gastric lesions. Sections were obtained for morphological studies, the mucosa was then scraped, and samples taken for determination of leukotrienes.

To assess the effect of scavengers, chelating agents, and proteins on the ethanol induced injury, rats were treated intragastrically with either catalase, bovine serum albumin, superoxide dismutase, $\mathrm{Mn}-\mathrm{DF}$, or 2,2-dipyridyl 5-15 minutes before intragastric administration of $1 \mathrm{ml} 96 \%$ ethanol.

To attenuate gastric acid secretion and maintain neutral $\mathrm{pH}$ in the stomach, in certain experiments, rats were treated intragastrically with ranitidine $(75 \mathrm{mg} / \mathrm{kg}$ bw) 30 minutes before intragastric administration of TEMPOL followed five minutes later by intragastric administration of $1 \mathrm{ml} 96 \%$ ethanol. Control animals in this experiment received ranitidine and ethanol.

When gastric mucosal damage was induced by NSAIDs, rats received intragastric $0.1 \mathrm{~g}$ nitroxide/kb bw, five minutes before or one hour and two hours after subcutaneous injections of indomethacin ( $30 \mathrm{mg} / \mathrm{kb} \mathrm{bw})$ or intragastric administration of aspirin $(0.1 \mathrm{~g} / \mathrm{kg} \mathrm{bw})$. In these experiments, rats were killed three hours after NSAID administration.

To assess the nitroxide protection from gastric damage induced by acid or $25 \% \mathrm{NaCl}$, TEMPOL was given five minutes before intragastric administration of either $1 \mathrm{ml} 0.6$ $\mathrm{N} \mathrm{HCl}$ or $25 \% \mathrm{NaCl}$. Control rats were treated with the irritants only; all rats were killed one hour after damage induction.

DETERMINATION OF LEUKOTRIENES

Samples $(150 \mathrm{mg}$ ) of mucosa were placed in pre-weighed tubes containing $1 \mathrm{ml}$ of $50 \mathrm{mM}$ 
phosphate buffer, $\mathrm{pH} 7 \cdot 4$ minced with scissors, and centrifuged in an Eppendorf centrifuge for 10 seconds. The pellet was resuspended in $1 \mathrm{ml}$ of the above buffer, incubated for one minute in a vortex mixer, $10 \mu \mathrm{g}$ indomethacin was added, and the tubes were centrifuged for 60 seconds. The supernatants were kept at $-20^{\circ} \mathrm{C}$ until radioimmunoassay(s) were performed. The capability of the mucosa to generate leukotriene $\mathrm{C}_{4}$ and leukotriene $\mathrm{B}_{4}$ was expressed as ng/g wet tissue weight.

\section{MEASUREMENT OF LEUKOTRIENE $B_{4}$}

Immunoreactivity of leukotriene $\mathrm{B}_{4}$ was determined by radioimmunoassay kit (Amersham, TRK 940). The assay combines the use of a high specific activity leukotriene $\mathrm{B}_{4}$ tracer, an antiserum specific for leukotriene $\mathrm{B}_{4}$ (cross reactivity $100 \%$ ), and leukotriene standard (range 1.6-200 pg/tube). The specific binding of tracer is $42 \cdot 5 \%$, non-specific binding $2 \cdot 4 \%$. Fifty per cent $\mathrm{B} / \mathrm{B}_{\mathrm{o}}$ displacement is obtained with $15 \mathrm{pg} /$ tube and $90 \% \mathrm{~B} / \mathrm{B}_{\mathrm{o}}$ displacement with $2 \cdot 2 \mathrm{pg} /$ tube of leukotriene $\mathrm{B}_{4}$.

\section{MEASUREMENT OF LEUKOTRIENE $\mathrm{C}_{4}$}

Immunoreactivity of leukotriene $\mathrm{C}_{4}$ was determined by a radioimmunoassay kit (Amersham, TRK 905). The assay combined the use of a high specific activity leukotriene $\mathrm{C}_{4}$ tritiated tracer with a monoclonal antibody specific for leukotriene $\mathrm{C}_{4}$ and leukotriene $\mathrm{C}_{4}$ standard. The standard curve covers the range 8-500 $\mathrm{pg} /$ tube and was performed in serial dilution. The assay uses highly specific leukotriene $\mathrm{C}_{4}$ antiserum (cross reactivity $100 \%$ ) and has low cross reactivity with leukotriene $\mathrm{D}_{4}(<5 \%)$. The specific binding of tracer is $40.2 \%$, nonspecific binding $3 \%$. $\mathrm{B} / \mathrm{B}_{\mathrm{o}}$ displacement of $50 \%$ is obtained with $34 \mathrm{pg} /$ tube and $80 \% \mathrm{~B} / \mathrm{B}_{\mathrm{o}}$ displacement with $9.5 \mathrm{pg} /$ tube of leukotriene $\mathrm{C}_{4}$.

Radioimmunoassay was performed as follows: $100 \mu \mathrm{l}$ of either standard or sample

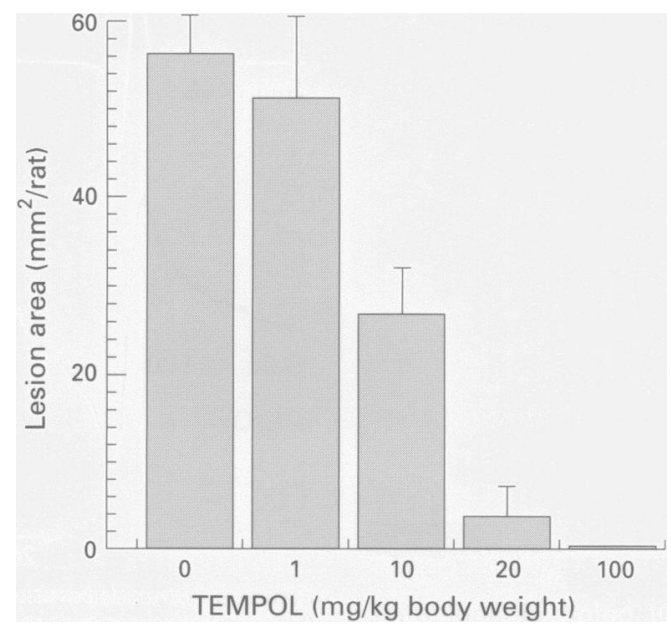

Figure 1: Effect of TEMPOL on ethanol induced gastric mucosal damage. Rats were treated with intragastric TEMPOL 5 minutes before intragastric administration of $1 \mathrm{ml} 96 \%$ ethanol. The rats were killed 10 minutes after ethanol administration, and the area of macroscopically visible gastric lesions was measured. macroscopically visible gastri
Results are mean (SEM). buffer were pipetted to assay tubes and $100 \mu \mathrm{l}$ antibody was added to all tubes except for total and blank tubes. The tubes were incubated at $4^{\circ} \mathrm{C}$ for 30 minutes. $100 \mu l$ tritiated leukotriene were added to all tubes and incubated at $4^{\circ} \mathrm{C}$ overnight. $200 \mu$ l buffer was added, followed by $200 \mu l$ dextran coated charcoal solution, excluding the total tube to which $200 \mu \mathrm{l}$ buffer was added. The tubes were vortexed, incubated at $4^{\circ} \mathrm{C}$ for 10 minutes, and centrifuged in a refrigerated Beckman centrifuge at $1600 \mathrm{~g}$ for 10 minutes. The supernatant was transferred to scintillation vials to which $7 \mathrm{ml}$ scintillation fluid was added and counted in a Kontron liquid scintillation counter.

\section{MORPHOLOGICAL STUDIES}

Sections of the gastric mucosa from five representative rats of each treatment group were fixed in phosphate buffered formaldehyde, embedded in paraffin wax, and routine $5 \mu \mathrm{m}$ sections were prepared. Tissues were routinely stained with haematoxylin and eosin and blindly evaluated for severity of damage by light microscopy.

\section{STATISTICAL ANALYSIS}

The data are expressed as the mean (SEM) of the number of rats in each experimental group. Statistical comparisons for parametric data were made by Student's $t$ test for unpaired data. The Mann-Whitney U test for statistical comparisons of non-parametric data was also used. A probability of $\mathrm{p}<0.05$ was considered as statistically significant.

\section{Results}

EFFECT ON GASTRIC MUCOSAL LESIONS

Figure 1 shows the effect of $96 \%$ ethanol when given by itself or after pre-treatment with TEMPOL, on the gastric mucosa. In ethanol treated rats, lesion area averaged 56 (4) $\mathrm{mm}^{2} / \mathrm{rat}(\mathrm{n}=48)$, which represent about $10 \%$ of the glandular part of the stomach. Figure 1 shows that intragastric pre-administration of TEMPOL dose dependently decreased the extent of damage. Nitroxide at $0.1 \mathrm{~g} / \mathrm{kg}$ bw totally prevented the ethanol induced mucosal lesions. As cultured mammalian cells tolerated up to $1 \mathrm{mM}$ TEMPOL, ${ }^{11}$ only subtoxic concentrations of nitroxide were used and the average TEMPOL concentration used in this study did not exceed $0.5 \mathrm{mM}$. In control experiments, no adverse effects in TEMPOL treated rats were detected for a week.

HISTOLOGICAL FINDINGS

Histological sections from the gastric wall of rats treated with $96 \%$ ethanol showed multiple mucosal lesions. The erosions were sharply demarcated from the surrounding mucosa with considerable congestion, oedema, and acute inflammatory infiltrate underneath (Fig $2 \mathrm{~A}$ ). In rats pre-treated with $0 \cdot 1 \mathrm{~g} / \mathrm{kg}$ bw TEMPOL, the gastric mucosa was normal and could not 


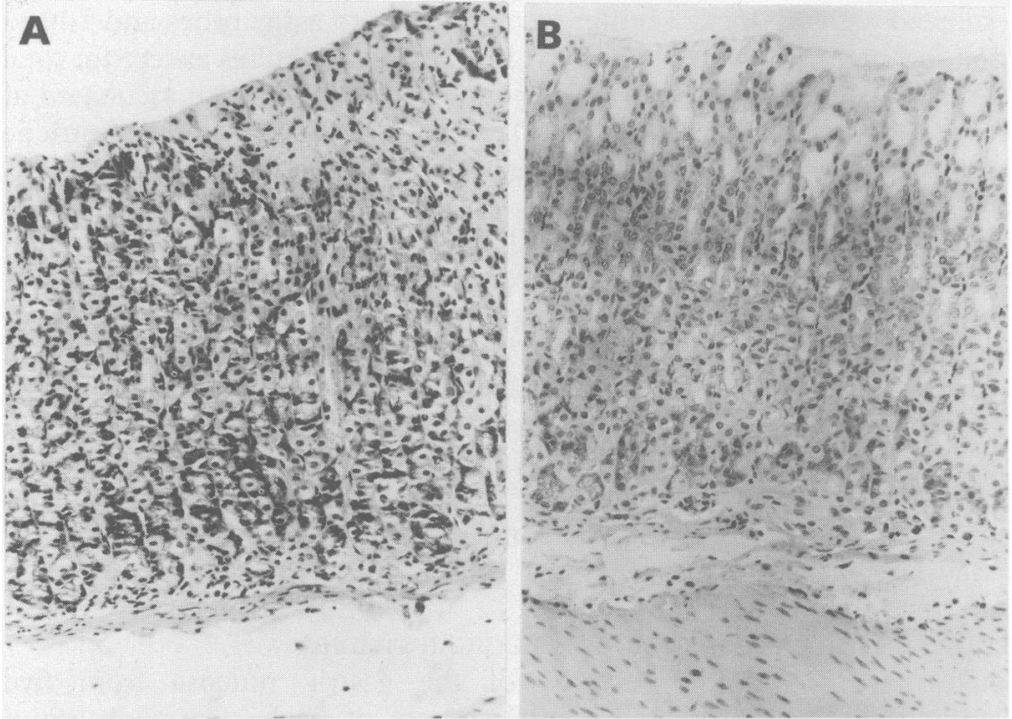

Figure 2: Histological sections (haematoxylin and eosin, original magnification $\times 173$ ) of gastric mucosa of rats treated with $1 \mathrm{ml} 96 \%$ ethanol only $(A)$; or after pre-treatment with TEMPOL $0 \cdot 1 \mathrm{~g} / \mathrm{kg}$ bw (B). (A) shows (on top right side) an erosion that is sharply demarcated from the surrounding mucosa with considerable congestion, oedema, and acute inflammatory infiltrate underneath. (B) a section obtained from rats pre-treated with TEMPOL $0 \cdot 1 \mathrm{~g} / \mathrm{kg}$ bw, shows normal gastric mucosa.

be distinguished from that in control rats. The surface epithelium of the entire mucosa was examined and found to be totally protected and normal looking (Fig 2B).

TIME DEPENDENCE OF NITROXIDE EFFECT To examine the duration of the nitroxide effect, rats were treated with intragastric nitroxide at various periods before induction of damage. TEMPOL $0 \cdot 1 \mathrm{~g} \mathrm{~kg}$, when given 30 or 60 minutes before administration of ethanol, prevented lesion formation (Fig 3). With a lower dose of $20 \mathrm{mg}$ nitroxide/ $/ \mathrm{kg}$ bw, given 30 minutes and 60 minutes before ethanol, the protection was partial and lesion area decreased by $76 \%$ and $45 \%$ respectively. When TEMPOL $(0.1 \mathrm{~g} / \mathrm{kg} \mathrm{bw})$ was given 5 minutes after ethanol administration, no

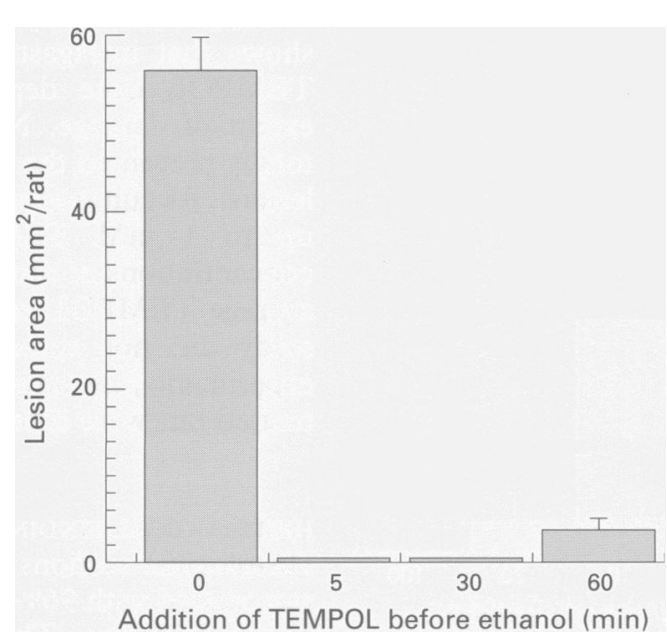

Figure 3: Protection by TEMPOL given at various time intervals before ethanol administration. Rats were treated, intragastrically with TEMPOL $0.1 \mathrm{~g} / \mathrm{kg}$ bw at various time intervals before intragastric administration of $1 \mathrm{ml}$ $96 \%$ ethanol. Rats were killed after 10 minutes and the area of macroscopically visible gastric lesions was measured. Results are mean (SEM). protection was seen (61 (9) and $56(4) \mathrm{mm}^{2} / \mathrm{rat}$ respectively).

\section{PARTITION OF NITROXIDE INTO CELLS}

To ascertain that TEMPOL does indeed enter the mucous cells, the effect of an extracellular paramagnetic line broadening agent on the EPR signal of the nitroxide was examined. In principle, a distinction between the EPR signals arising from intra and extracellular species can be achieved with selective line broadening agents that cannot readily enter the cells. CrOx, which was previously found to be superior to ferricyanide or $\mathrm{Ni}(\mathrm{II}),{ }^{27}$ was used in our study. After mixing $40 \mu l$ of $300 \mathrm{mM} \mathrm{CrOx}$ with $40 \mu \mathrm{l}$ of $10 \mathrm{mM}$ TEMPOL, the EPR signal of the nitroxide disappeared (data not shown). Later, immediately after the addition of a tissue sample of gastric mucosa to the solution, the EPR signal of TEMPOL has been instantaneously restored. Figure 4 shows the results of a typical experiment that compares the EPR signal seen upon scanning a sample containing $38 \mathrm{mg}$ wet weight gastric mucosa soaked with $40 \mu$ l of $5 \mathrm{mM}$ TEMPOL in phosphate buffered saline, before (upper spectrum) and immediately after the addition of $40 \mu \mathrm{l}$ of $300 \mathrm{mM} \mathrm{CrOx}$ (lower spectrum). As Fig 4 shows, the intensity of the restored signal, because of the intracellular TEMPOL species inaccessible to the line broadening agent, represented only a small fraction of the total signal, reflecting the volume fraction occupied by the cells. The results showed that TEMPOL readily enters the mucous cells, as previously found for isolated cells in tissue culture. ${ }^{28}$ The TEMPOL distribution between the intra and extracellular compartments is readily evaluated from the respective spectra. The volume fraction occupied by the cells and inaccessible for $\mathrm{CrOx}$ is less than $15 \%$ of the total sample volume $(38 \mathrm{mg}$ of gastric mucosa containing about $15 \mathrm{mg}$ of mucous cells immersed in a
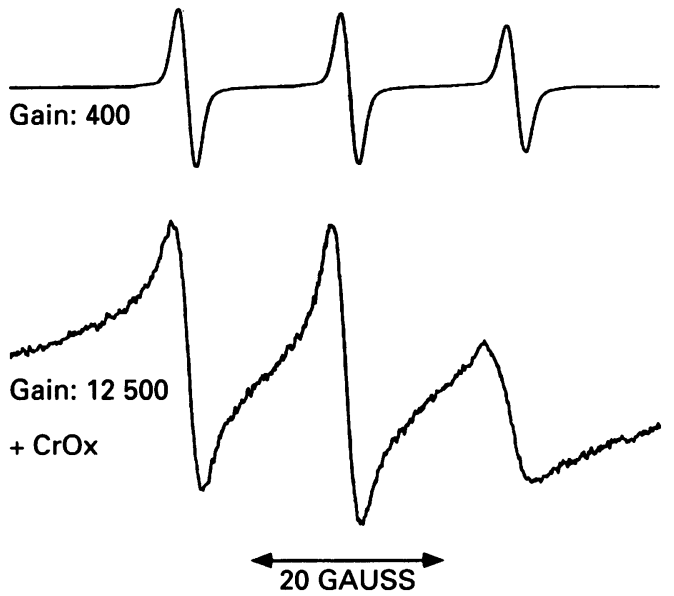

Figure 4: Nitroxide partition into mucous cells. Electron paramagnetic resonance spectra recorded for tissue sample of gastric mucosal soaked with $5 \mathrm{mM}$ TEMPOL in $0 \cdot 1 \mathrm{M}$ pH7, phosphate buffered saline before (upper spectrum, gain=400) and immediately after the additon of $\mathrm{CrOx}$ (lower spectrum, gain $5=12500$ ). Experimental conditions: room temperature, aerobic conditions, $9.45 \mathrm{GHz}$, 3360 Gauss centre field, $10 \mathrm{~mW}$ incident microwave power, and $1 G$ modulation amplitude. 
TABLE I Effect of catalase, superoxide dismutase, bovine serum albumin (BSA), superoxide dismutase-mimic and chelating agents on gastric mucosal lesions induced by ethanol

\begin{tabular}{|c|c|c|c|}
\hline Additive & Rats (n) & $\begin{array}{l}\text { Time before administration } \\
\text { of ethanol (min) }\end{array}$ & $\begin{array}{l}\text { Lesion area } \\
\mathrm{mm}^{2} / \text { rat }\end{array}$ \\
\hline Control ethanol only & 48 & & $56(4)$ \\
\hline Catalase (Sigma), $50000 \mathrm{U} / \mathrm{kg}$ bw & 5 & 5 & $8 \cdot 4(2 \cdot 6)^{\star}$ \\
\hline Catalase (Sigma), $50000 \mathrm{U} / \mathrm{kg} \mathrm{bw}$ & 10 & 15 & $40(14)$ \\
\hline Catalase (Boeheringer), $50000 \mathrm{U} / \mathrm{kg}$ bw & 5 & 5 & $42(8)$ \\
\hline $\mathrm{BSA}, 15 \mathrm{mg} / \mathrm{kg}$ bw & 5 & 5 & $18(7 \cdot 6)^{\star}$ \\
\hline $\mathrm{BSA}, 15 \mathrm{mg} / \mathrm{kg}$ bw & 5 & 10 & $33(10 \cdot 7)$ \\
\hline BSA, $15 \mathrm{mg} / \mathrm{kg}$ bw & 5 & 15 & $90(13)$ \\
\hline Superoxide dismutase $12000 \mathrm{U} / \mathrm{kg}$ bw & 10 & 5 & $56(12)$ \\
\hline Superoxide dismutase $60000 \mathrm{U} / \mathrm{kg}$ bw & 10 & 5 & $19(6 \cdot 3)$ \\
\hline Superoxide dismutase $60000 \mathrm{U} / \mathrm{kg} \mathrm{bw}$ & 9 & 15 & $24(7 \cdot 8)^{\star}$ \\
\hline \multicolumn{4}{|l|}{ Inactive superoxide dismutase } \\
\hline $60000 \mathrm{U} / \mathrm{kg} \mathrm{bw}$ & 5 & 5 & $37(7 \cdot 8)$ \\
\hline $\mathrm{Mn}-\mathrm{DF}, 0 \cdot 1 \mathrm{~g} / \mathrm{kg}$ bw & 8 & 5 & $37(7 \cdot 8)$ \\
\hline $\mathrm{DF}, 0 \cdot 1 \mathrm{~g} / \mathrm{kg} \mathrm{bw}$ & 10 & 5 & $38(9 \cdot 2)$ \\
\hline 2,2dipyridyl, $0 \cdot 1 \mathrm{~g} / \mathrm{kg}$ bw & 5 & 5 & $63(19)$ \\
\hline
\end{tabular}

The additives were given intragastrically before treatment of the rats with $1 \mathrm{ml} 96 \%$ ethanol. The rats were killed 10 minutes later and mucosal lesions measured. Results are mean (SEM) for rats in each group. ${ }^{\star}$ Significantly different from rats treated with ethanol alone.

total volume of $118 \mu \mathrm{l}$ ). Taking into account the respective $2: 1$ ratio in signal heights shown in Fig 4 and a 1:31 ratio of spectrometer gain yields a ratio of $1: 2$ for nitroxide concentration inside and outside the cells.

PERSISTENCE OF NITROXIDE IN THE MUCOSAL COMPARTMENT

To evaluate the persistence of the nitroxide in the mucosal tissue, rats were treated intragastrically with $0.1 \mathrm{~g} / \mathrm{kg}$ bw TEMPOL, either five minutes or 60 minutes before administration of $1 \mathrm{ml}$ saline or ethanol $96 \%(\mathrm{n}=4)$. Five minutes later, the rats were killed $20 \mathrm{mg}$ wet weight samples were excised from the gastric mucosal tissue, blended in $1 \mathrm{ml}$ phosphate buffered saline, and frozen. To estimate the residual nitroxide concentration in the tissue, the frozen suspension were thawed, samples of $100 \mu \mathrm{l}$ were drawn into a Teflon capillary, placed in the EPR cavity, and the EPR spectrum of the TEMPOL was recorded (see methods). Because TEMPOL predominantly decays within cells by reduction to the hydroxy-

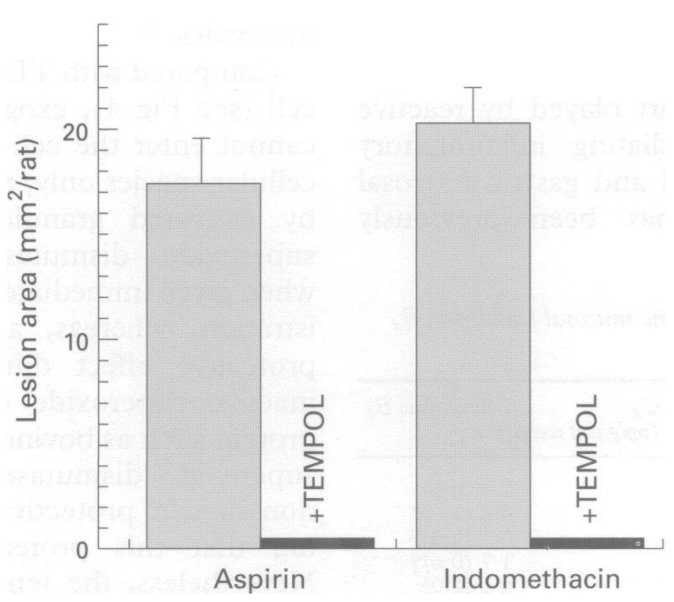

Figure 5: Effect of nitroxides on NSAID induced gastric mucosal lesion. Rats, fasted overnight, were treated intragastrically with $0 \cdot 1 \mathrm{~g}$ TEMPOL/kg bw, five minutes before as well as one hour and two hours after subcutaneous administration of indomethacin $(30 \mathrm{mg} / \mathrm{kg} \mathrm{bw})$ or intragastric administration of aspirin $(0.1 \mathrm{~g} / \mathrm{kg} \mathrm{bw})$. The rats were killed three hours after NSAID administration and the area of macroscopically visible gastric lesions was measured. lamine 4-hydroxy-2,2,6,6-tetramethyl-piperidine-1oxyl (TEMPOL-H), the total concentration of TEMPOL+TEMPOL-H was also evaluated. To oxidise the TEMPOL-H that was accumulated $2 \mu \mathrm{l}$ of $0.1 \mathrm{M} \mathrm{K}_{3} \mathrm{Fe}(\mathrm{CN})_{6}$ was added to each sample and the EPR spectrum was recorded again. From the intensity of the EPR signal, the total concentration of TEMPOL+TEMPOL-H was calculated, taking into account the respective dilutions. When TEMPOL was given five minutes before treatment with ethanol, the residual (TEMPOL) was $1.3 \quad(0.2) \quad \mathrm{mM}$ while $($ TEMPOL) + (TEMPOL-H) was $3.65(1 \cdot 1)$ $\mathrm{mM}$. When TEMPOL was given 60 minutes before treatment with ethanol the respective values were: $0.32(0.24) \mathrm{mM}$ and $1.7(0.65)$ $\mathrm{mM}$. This shows that after one hour, the total concentration of TEMPOL decreased by half, from which, over $80 \%$ was reduced to TEMPOL-H. This explains the decrease with time in the protective effect of nitroxide (see Fig 3).

\section{EFFECT OF PH}

To find out if acidic $\mathrm{pH}$ was required for the protective activity of TEMPOL, its effect on gastric mucosal injury in ranitidine treated rats was studied. Under such conditions, gastric acid secretion was inhibited, the $\mathrm{pH}$ remained neutral, and no free gastric acid was detectable. Administration of ethanol, in the absence of TEMPOL, 30 minutes after treatment with ranitidine resulted in lesion areas of $55(10) \mathrm{mm}^{2} / \mathrm{rat}(\mathrm{n}=7)$. Conversely, in ranitidine treated rats, a pre-treatment with TEMPOL totally prevented ethanol induced gastric damage, showing that neither the extent of damage nor the protective effect of TEMPOL differ from these obtained under normal gastric $\mathrm{pH} 1 \cdot 7$.

EFFECT OF EXOGENOUS CATALASE, SUPEROXIDE DISMUTASE, AND BOVINE SERUM ALBUMIN

As the deleterious effect of ethanol is exerted in fasted, but not fed, animals, the intragastric administration of enzymic protein might have some non-specific effect resembling that of rat feeding. To distinguish between specific and non-specific protective effects, the effects of intragastric administration of superoxide dismutase, inactive superoxide dismutase, catalase, and bovine serum albumin was studied. In addition, the time interval between the administration of protein and ethanol was varied. When given five minutes before ethanol, even a foreign protein such as bovine serum albumin or inactive superoxide dismutase, diminished the extent of gastric mucosal lesions. Similarly, the protection afforded by catalase of Boheringer was smaller than that exerted by catalase of Sigma, which contained sixfold more protein (Table I). When bovine serum albumin was given 10-15 minutes before ethanol, however, no protection against ulceration was evident. 
TABLE II Effect of acid, $25 \% \mathrm{NaCl}$, and TEMPOL on gastric mucosal lesions and eicosanoids

\begin{tabular}{|c|c|c|c|c|}
\hline Treatment & $\begin{array}{l}\text { Rats } \\
(n)\end{array}$ & $\begin{array}{l}\text { Leukotriene } C_{4} \\
\text { (ng/g a }\end{array}$ & $\begin{array}{l}\text { Leukotriene } B_{4} \\
\text { weight) }\end{array}$ & $\begin{array}{l}\text { Lesions } \\
\left(\mathrm{mm}^{2} / \text { rat }\right)\end{array}$ \\
\hline $\begin{array}{l}0.6 \mathrm{~N} \mathrm{HCl} \\
0.6 \mathrm{~N} \mathrm{HCl}+\text { TEMPOL } \\
25 \% \mathrm{NaCl} \\
\text { TEMPOL }+25 \% \mathrm{NaCl}\end{array}$ & $\begin{array}{l}9 \\
10 \\
14 \\
9\end{array}$ & $\begin{array}{l}8 \cdot 2(0 \cdot 9) \\
6 \cdot 8(0 \cdot 6) \\
6 \cdot 1(1 \cdot 4) \\
8 \cdot 9(1 \cdot 0)\end{array}$ & $\begin{array}{l}6 \cdot 4(1 \cdot 0) \\
3 \cdot 6(0 \cdot 5)^{\star} \\
1 \cdot 0(0 \cdot 3) \\
0 \cdot 2(0 \cdot 03)\end{array}$ & $\begin{array}{c}106(18) \\
28(7)^{\star} \\
34(10) \\
0^{\star}\end{array}$ \\
\hline
\end{tabular}

TEMPOL $(0 \cdot 1 \mathrm{~g} / \mathrm{kg} / \mathrm{bw})$ was given intragastrically 5 minutes before intragastric administration of saline or irritant. Rats were killed 60 minutes later, mucosal lesions were measured and eicosanoids were determined as described in methods. Results are mean (SEM) for rats in each group. ${ }^{\star}$ Significantly different from rats treated with $0.6 \mathrm{~N} \mathrm{HCl}$ or $25 \% \mathrm{NaCl}$ alone.

\section{EFFECT OF MN-DF SUPEROXIDE}

DISMUTASE-MIMIC

Mn-DF, a low molecular weight, cell permeable, superoxide dismutase-mimic, is reportedly effective in protecting various cells against superoxide induced damage. ${ }^{23}$ Pre-treatment with Mn-DF before ethanol administration, however, did not decrease the extent of gastric mucosal injury (Table I) to any statistically significant extent.

\section{PROTECTION BY TEMPOL AGAINST DAMAGE} INDUCED BY NSAIDS AND OTHER IRRTTANTS The protection provided by nitroxide was also evaluated with respect to damage induced by NSAIDs and other irritants. TEMPOL (three doses, each of $0 \cdot 1 \mathrm{~g} / \mathrm{kg} \mathrm{bw}$ ) prevented gastric ulceration induced by either indomethacin or aspirin (Fig 5). Similarly, pre-treatment with TEMPOL $(0 \cdot 1 \mathrm{~g} / \mathrm{kg} \mathrm{bw})$ prevented gastric lesions induced by $25 \% \mathrm{NaCl}$ and partially protected from $0.6 \mathrm{NN} \mathrm{HCl}$ (Table II).

EFFECT ON GASTRIC MUCOSAL MEDIATORS

The generation of mucosal leukotriene $\mathrm{B}_{4}$ and $\mathrm{C}_{4}$, was increased two to threefold 10 minutes after damage induction by ethanol compared with their generation in saline treated rats (Table III). TEMPOL at $0 \cdot 1 \mathrm{~g} / \mathrm{kg}$ bw prevented the ethanol induced increase in leukotriene $C_{4}$ and $B_{4}$ generation $(p<0.05$, Mann-Whitney test, Table III).

\section{Discussion}

Evidence for the key part played by reactive oxygen species in mediating inflammatory bowel disease in general and gastric mucosal injury in particular, has been previously

TABLE III Effect of ethanol, NSAIDs, and TEMPOL on gastric mucosal leukotrine $B_{4}$ and leukotriene $C_{4}$

\begin{tabular}{lccc}
\hline Treatment & Rats $(n)$ & $\begin{array}{c}\text { Leukotriene } C_{4} \\
(\text { ng/g wet weight) }\end{array}$ \\
\hline Saline & $30-31$ & $3 \cdot 6(0 \cdot 7)$ & $2 \cdot 4(0 \cdot 5)$ \\
Ethanol & $14-32$ & $11 \cdot 3(1 \cdot 6)^{\star}$ & $6 \cdot 2(1 \cdot 0)^{\star}$ \\
TEMPOL & 10 & $2 \cdot 4(0 \cdot 7)$ & $0 \cdot 7(0 \cdot 3)^{\star}$ \\
TEMPOL+ethanol & $9-10$ & $5 \cdot 3(0 \cdot 6) \dagger$ & $1 \cdot 7(0 \cdot 6) \dagger$ \\
Indomethacin & 10 & $2 \cdot 1(0 \cdot 4)$ & $4 \cdot 1(1 \cdot 0)$ \\
TEMPOL+Indomethacin & 10 & $2 \cdot 1(0 \cdot 3)$ & $2 \cdot 6(0 \cdot 5)$ \\
Aspirin & 5 & $1 \cdot 2(0 \cdot 06)$ & $1 \cdot 5(0 \cdot 3)$ \\
Aspirin+TEMPOL & 10 & $2 \cdot 3(0 \cdot 5)$ & $1 \cdot 8(0 \cdot 2)$ \\
\hline
\end{tabular}

TEMPOL $(0 \cdot 1 \mathrm{~g} / \mathrm{kg} \mathrm{bw})$ was given intragastrically five minutes before intragastric administration of saline or $96 \%$ ethanol. Rats were killed 10 minutes later and leukotriene $\mathrm{B}_{4}$ and leukotriene $\mathrm{C}_{4}$ were determined as described in methods. The control values of $\mathrm{B}_{4}$ and leukotriene $\mathrm{C}_{4}$ were determined as described in methods. The control values of leukotriene $\mathrm{B}_{4}$ and leukotriene $\mathrm{C}_{4}$ were the same with and without saline treatment. Res tsignificantly different from ethanol treated or NSAIDs treated rats. reported for diverse types of stress. ${ }^{1-7} 29-36$ The central finding of this study is that TEMPOL provided total protection from gastric mucosal injury induced by alcohol and NSAIDs. Moreover, this protection was prolonged even when the nitroxide was given one hour before initiating damage. Nitroxide stable radicals selectively react with free radicals and with other paramagnetic species. As such, nitroxides serve not only as radical chain reaction terminators and effective cytoprotective agents, but also as sensitive probes for free radical mediated processes. Therefore, the complete protection provided by TEMPOL confirms the role of free radicals and redox active metals in ethanol induced cellular damage in general ${ }^{37}$ and in the pathogenesis of gastric mucosal injury.

ROLE OF EXTRACELLULAR $\mathrm{O}_{2}^{-}$

Previous reports of protective effects of chelating agents, catalase, and superoxide dismutase, implicated reactive oxygen species in either triggering gastric mucosal lesions or contributing to the development of necrosis once the process has started. ${ }^{16}$ According to this hypothesis $\mathrm{O}_{2}^{-}, \mathrm{H}_{2} \mathrm{O}_{2}$, and $\cdot \mathrm{OH}$ or hypervalent metal are instrumental in the pathogenesis of gastric mucosal injury by a metal catalysed Haber-Weiss reaction (L denotes some cellular ligand that binds the metal):

$$
\begin{aligned}
& \mathrm{L}-\mathrm{M}^{\mathrm{n}+}+\mathrm{O}_{2}^{-} \quad \rightarrow \mathrm{L}-\mathrm{M}^{(\mathrm{n}-1)+}+\mathrm{O}_{2} \\
& \mathrm{~L}-\mathrm{M}\left({ }^{\mathrm{n}-1)+}+\mathrm{H}_{2} \mathrm{O}_{2} \rightarrow \mathrm{L}-\mathrm{M}^{(\mathrm{n}-1)+}-\mathrm{H}_{2} \mathrm{O}_{2}\right. \\
& \mathrm{L}-\mathrm{M}\left({ }^{\mathrm{n}-1)+}-\mathrm{H}_{2} \mathrm{O}_{2} \rightarrow \mathrm{L}-\mathrm{M}^{(\mathrm{n})+}+\mathrm{OH}^{-}+\cdot \mathrm{OH}[5 \mathrm{a}]\right. \\
& \mathrm{L}-\mathrm{M}\left({ }^{\mathrm{n}-1)+}-\mathrm{H}_{2} \mathrm{O}_{2} \rightarrow \mathrm{L}-\mathrm{M}^{(\mathrm{n}+1)+}+2 \mathrm{OH}^{-}\right.
\end{aligned}
$$

Practically, however, under normal gastric $\mathrm{pH}$ of 1.7 the superoxide radical anion does not exist. The hydroperoxyl radical $\mathrm{HO}_{2}$, the protonated form of superoxide, is much less oxidisable than $\mathrm{O}_{2}^{-}$and has been previously shown to react faster than superoxide with nitroxides. ${ }^{38}$

Compared with TEMPOL, which enters the cell (see Fig 4), exogenously added enzymes cannot enter the cell and can detoxify extracellular species only, probably those generated by activated granulocytes. ${ }^{6}$ In this study, superoxide dismutase protected primarily when given immediately before ethanol administration, whereas, a few minutes later its protective effect diminished. Moreover, as inactive superoxide dismutase or a foreign protein such as bovine serum albumin, lacking superoxide dismutase activity showed some non-specific protective effect, it is not surprising that this protection rapidly subsided. Nevertheless, the temporal relation, between the protecting agent and the initiation of gastric mucosal damage does not exclude a contribution of exogenous superoxide. A previous study ${ }^{39}$ showed that addition of superoxide dismutase, with or without catalase, only slightly (twofold) decreased the indomethacin induced lesion area. Conversely, 
nitroxides, which act both intra and extracellulary are fully protected. The dramatic difference between the effects of superoxide dismutase and nitroxide clearly shows the important part played by intracellular radicals.

In this study, Mn-DF did not show any protection. This synthetic superoxide dismutase-mimic, which reportedly ${ }^{23}$ can provide cytoprotection by removing $\mathrm{O}_{2}^{-}$is prone to dissociate in biological systems and lose its catalytic activity. ${ }^{24}$ Therefore, the failure of Mn-DF to prevent gastric mucosal injury does not necessarily exclude the role of intracellular $\mathrm{O}_{2}^{-}$toward mucosal damage.

A similar conclusion can be drawn from the failure of DF to provide protection. DF is a chelating agent, which avidly binds transition metal ions ${ }^{40}$ particularly iron (III); however, because it enters the cell very slowly ${ }^{8}$ the cytoprotective effect of $\mathrm{DF}$ requires about one hour of preincubation. As Table I shows, DF did not provide protection against gastric mucosal injury.

\section{MECHANISM OF NITROXIDE ACTION}

Reactions of free radicals with diamagnetic molecules yield secondary radicals, which might propagate injurious process. Conversely, nitroxides, which are free radicals themselves, terminate radical chain reactions. Several mechanisms might underly the nitroxides effect on the biological damage, all of which entail reaction with paramagnetic species. Firstly, five membered ring nitroxides have been found capable of catalytically dismutating $\mathrm{O}_{2}^{--}$. Both the nitroxide and its respective hydroxylamine can react with $\mathrm{O}_{2}^{-}$yielding $\mathrm{O}_{2}$ and $\mathrm{H}_{2} \mathrm{O}_{2}$, whereas the concentration ratio of the redox couple [nitroxide]/[hydroxylamine] remains time invariant and independent of $\mathrm{O}_{2}^{-}$ flux. ${ }^{38}$ Secondly, more recently, 6 membered ring nitroxide derivatives were found to remove $\mathrm{O}_{2}^{-}$by a different, yet catalytic, mode. Both the nitroxide and its respective oxoammonium cation, acting as an superoxide dismutase mimic, rapidly react with $\mathrm{O}_{2}^{-}$, yielding $\mathrm{H}_{2} \mathrm{O}_{2}$ and $\mathrm{O}_{2}{ }^{41}$ :

Note that generally the concentration of cellular enzymes is dwarfed by that of their respective substrates. The exception for this rule are cellular superoxide dismutase and nitroxide superoxide dismutase-mimics whose concentrations exceeds that of $\mathrm{O}_{2}^{-}$by several orders of magnitude. Thirdly, both 5 and 6

$$
\begin{aligned}
& { }_{\mathrm{HO}}^{\mathrm{N}_{\mathrm{N}}-\mathrm{O}}+\mathrm{O}_{2}^{-}+2 \mathrm{H}^{+} \Rightarrow \mathrm{HO}_{\mathcal{X}^{+\mathrm{N}}=\mathrm{O}}^{+}+\mathrm{H}_{2} \mathrm{O}_{2}[6]
\end{aligned}
$$

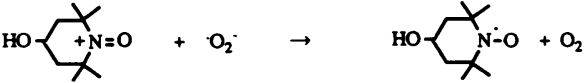

membered ring nitroxides have been found to protect cells through reaction with reduced metal ions. 'Normally', in aerated systems, reduced redox active metal ions react with
$\mathrm{H}_{2} \mathrm{O}_{2}$ yielding a peroxo complex (reaction 4). As cellular transition metals do not exist as 'free' ions, but rather coordinated to cellular components, deleterious species, such as authentic secondary $\mathrm{OH}$ (reaction $5 \mathrm{a}$ ) and hypervalent metal (reaction 5b), are formed 'site specifically' in a close proximity to critical biological targets. This site specific formation is responsible for damage potentiation and accounts for the frequent failures of radical scavengers to provide protection. ${ }^{4243}$ The reactions of nitroxides with transition metals have been previously studied and reported. ${ }^{819}$ These results suggested that nitroxides can compete with $\mathrm{H}_{2} \mathrm{O}_{2}$ and oxidise the reduced metal ions ${ }^{19}$ :

$$
\begin{aligned}
& \mathrm{L}-\mathrm{M}\left({ }^{\mathrm{n}-1}\right)++\mathrm{H}^{+}+\text {nitroxide } \\
& \mathrm{L}-\mathrm{M}^{\mathrm{n}+}+\text { hydroxylamine }
\end{aligned}
$$

thus inhibiting reaction 4 . Finally, nitroxides have been previously shown to protect hypoxic cells also where reactive oxygen species are practically absent. The hypoxic cytotoxicity of either $t-\mathrm{BuOOH}^{8}$ or mitomycin $\mathrm{c}^{21}$ to Chinese hamster cells could be totally eliminated by nitroxides. While $t-\mathrm{BuOOH}$ induced toxicity is catalysed by transition metals, that of mitomycin $\mathrm{c}$ is not. The cytoprotective effect of TEMPOL, in the last case, was attributed to the rapid removal of the deleterious semiquinone radicals of mitomycin c through reaction with nitroxide. ${ }^{21}$

The findings of this study confirmed that in ethanol treated rats, the generation of gastric mucosal leukotriene $\mathrm{B}_{4}$ and leukotriene $\mathrm{C}_{4}$ increases, suggesting that they participate in some fashion in the pathogenesis of the damage. ${ }^{44}$ TEMPOL effectively prevented gastric mucosal damage (Figs 1 and 2) and attenuated the increase in leukotriene $\mathrm{B}_{4}$ and leukotriene $\mathrm{C}_{4}$ generation induced by ethanol (Table III). Yet, gastric mucosal generation of leukotrienes in rats treated with indomethacin or aspirin, did not change in the presence of nitroxide (Table III). These findings suggest that leukotrienes and platelet activating factor do not contribute toward gastric mucosal injury but are formed after damage induction after free radical generation. This may partly explain why specific receptor antagonists or synthesis blockers of leukotrienes do not provide total protection.

In conclusion, our results suggest that TEMPOL prevents gastric mucosal injury by breaking some chain reaction through a termination reaction with free radicals. Thus, the strategy of using selective radical-radical reactions to block biological damage, seems applicable also for the prevention of gastric injury. While the part played by free radicals in the mediation of gastric mucosal injury is well established and the potential of nitroxides

[7] for intervention is evidenced, further research is still needed to select better nitroxides and optimise their protective effect.

This research was partly supported by grant 89-00124 from the United States-Israel Binational Science Foundation (BSF), Jerusalem, Israel. The technical assistance of Ms R Carmeli and Ms L Rabi is greatly acknowledged. 
1 Pihan G, Regilo C, Szabo S. Free radicals and lipid peroxidation in ethanol-or aspirin-induced gastric mucosal injury. Dig Dis Sci 1987; 32: 1395-401.

2 Szelenyi I, Brune K. Possible role of oxygen free radicals in ethanol-induced gastric mucosal damage in rats. Dig Dis Sci 1988; 33: 865-71.

3 Terano A, Hiraishi H, Ota S, Shiga J, Sugimoto T. Role of superoxide and hydroxyl radicals in rat gastric mucosal injury induced by ethanol. Gastroenterol $f p n$ 1989; 24: injury indu

4 Salim AS. Removing oxygen-derived free radicals stimulates healing of ethanol-induced erosive gastritis in the rat. Digestion 1990; 47: 24-8.

5 Kvietys PR, Twohig B, Danzell J, Specian RD. Ethanolinduced injury to the rat gastric mucosa. Role of neutrophils and xanthine oxidase-derived radicals. Gastroenterology 1990; 98: 909-20.

6 Vaananen PM, Meddings JB, Wallace JL. Role of oxygenderived free radicals in indomethacin-induced gastric injury. Am F Physiol 1991; 261: G470-5.

7 Takeuchi K, Ushima K, Hironaka Y, Fujioka Y, Matsumoto J, Okabe S. Oxygen free radicals and lipid peroxidation in the pathogenesis of gastric mucosal lesions induced by indomethacin in rats. Digestion 1991; 49: induced $175-84$.

8 Mitchell JB, Samuni A, Krishna MC, DeGraff WG, Ahn MS, Samuni U, Russo A. Biologically active metalindependent superoxide dismutase mimics. Biochemistry 1990; 29: 2802-7.

9 Gelvan D, Saltman P, Powell SR. Cardiac reperfusion damage prevented by a nitroxide free radical. Proc Natal Acad Sci USA. 1991; 88: 4680-4

10 Hahn SM, Tochner Z, Krishna MC, Glass J, Wilson L, Samuni A, et al. Tempol, a stable free radical, is a nove murine radiation protector. Cancer Res 1992; 52: 1750-3.

11 Ankel EG, Lai CS, Hopwood LE, Zivkovic Z. Cytotoxicity of commonly used nitroxide radical spin probes. Life $\mathrm{Sci}$ 1987; 40: 495-8.

12 Froncisz W, Lai CS, Hyde JS. Spin-label oximetry: kinetic study of cell respiration using a rapid-passage T1-sensitive
electron spin resonance display. Proc Natl Acad Sci USA electron spin reso

13 Belkin S, Mehlhorn RJ, Packer $\amalg$. Electror: spin resonance oximetry. Methods Enzymol 1988; 167: 670-7.

14 Glockner JF, Chan HC, Swartzz HM. In vivo oximetry using a nitroxide-liposome system. Magn Reson Med 1991; 20: 123-33.

15 Bacic G, Nilges MJ, Magin RL, Walczak T, Swartz HM. In vivo localized ESR spectroscopy reflecting metabolism. Magn Reson Med 1989; 10: 266-72.

16 Keana JF, Pou S, Rosen GM. Nitroxides as potential contrast enhancing agents for MRI application: influence of structure on the rate of reduction by rat hepatocytes, whole liver homogenate, subcellular fractions, and ascorbate. Magn Reson Med 1987; 5: 525-36.

17 Nilsson US, Olsson LI, Carlin G, Bylund FA. Inhibition of lipid peroxidation by spin labels. Relationships of lipid peroxidation by spin labels. Relationships between $11131-5$.

18 Samuni A, Winkelsberg D, Pinson A, Hahn SM, Mitchell JB, Russo A. Nitroxide stable radicals protect beating cardiomyocytes against oxidative damage. $\mathcal{f}$ Clin Invest 1991; 87: 1526-30

19 Samuni A, Godinger D, Aronovitch J, Russo A, Mitchell JB. Nitroxides block DNA scission and protect cells from oxidative damage. Biochemistry 1991; 30: 555-61.

20 Pogrebniak H, Matthews W, Mitchell J, Russo A, Samuni A, Pass H. Spin trap protection from tumor necrosis factor cytotoxicity. ₹ Surg Res 1991; 50: 469-74

21 Krishna MC, DeGraff W, Tamura S, Gonzalez FJ, Samuni A, Russo A, et al. Mechanisms of hypoxic and aerobic cytotoxicity of mitomycin $\mathrm{C}$ in Chinese hamster V79 cells. Cancer Res 1991; 51: 6622-8.

22 Mitchell JB, DeGraff W, Kaufman D, Krishna MC, Samuni A, Finkelstein E, et al. Inhibition of oxygen-dependent radiation-induced damage by the nitroxide superoxide dismutase mimic, tempol. Arch Biochem Biophys 1991; 289: $62-70$.
23 Rabinowitch HD, Rosen GM, Fridovich I. A mimic of superoxide dismutase activity protects Chlorella sorokiniana against the toxicity of sulfite. Free Radic Biol Med 1989; 6: 45-8.

24 Hahn SM, Krishna CM, Samuni A, Mitchell JB, Russo A. $\mathrm{Mn}(\mathrm{III})$-desferrioxamine superoxide dismutase-mimic: alternative modes of action. Arch Biochem Biophys 1991; 288: $215-9$.

25 Bailar JC, Young EM. Trioxalato salts. Inorg Synth 1939; 1: 35-8.

26 Fridovich I. Quantitative aspects of the production of superoxide anion radical by milk xanthine oxidase. $7 \mathrm{Biol} \mathrm{Chem}$ 1970; 245: 4053-7.

27 Lai CS, Froncise W, Hopewood LE. An evaluation of paramagnetic broadening agents for spin probe studies of intact mammalian cells. Biophys $\mathcal{f} 1987 ; 52$ 625-8.

28 Samuni A, Carmichael AJ, Russo A, Mitchell JB, Riesz P. On the spin trapping and ESR detection of oxygenderived radicals generated inside cells. Proc Natl Acad Sci USA 1986; 83: 7593-7.

29 Grisham MB, Granger DN. Neutrophil-mediated mucosal injury. Role of reactive oxygen metabolites. Dig Dis $\mathrm{Sci}$ 1988; 33: $6-15 S$.

30 Szabo S. Gastroduodenal mucosal injury-acute and chronic: pathways, mediators, and mechanisms. $f$ Clin chronic: pathways, mediators,

31 Salim AS. Gastric mucosal cytoprotection in the rat by scavenging oxygen-derived free radicals. Am f Med Sci 1991; 302: $287-91$

32 Otamiri T, Sjodahl R. Oxygen radicals: their role in selected gastrointestinal disorders. Dig Dis 1991; 9: 133-41.

33 Mutoh H, Hiraishi H, Ota S, Ivey KJ, Terano A, Sugimoto $\mathrm{T}$. Role of oxygen radicals in ethanol-induced damage to cultured gastric mucosal cells. Am f Physiol 1990; 258: G603-9.

34 Hiraishi H, Terano A, Ota S, Mutoh H, Razandi M Sugimoto $\mathrm{T}$, et al. Role for iron in reactive oxygen speciesmediated cytotoxicity to cultured rat gastric mucosal cells. Am 7 Physiol 1991; 260: G556-63.

35 Yoshikawa T, Naito Y, Ueda S, Oyamada H, Takemura T, Yoshida N, et al. Role of oxygen-derived free radicals in the pathogenesis of gastric mucosal lesions in rats. $\mathcal{F}$ Clin Gastroenterol 1990; 12 (suppl I) S65-71.

36 Simmonds NJ, Allen RE, Stevens TR, Van SR, Blake DR Rampton DS. Chemiluminescence assay of mucosal reactive oxygen metabolites in inflammatory bowel disease. Gastroenterology 1992; 103: 186-96.

37 Nordmann R, Ribiere C, Rouach H. Implication of free radical mechanisms in ethanol-induced cellular injury. Free Radic Biol Med 1992; 12: 219-40.

38 Samuni A, Krishna CM, Riesz P, Finkelstein E, Russo A A novel metal-free low molecular weight superoxide dismutase mimic. F Biol Chem 1988; 263: 17921-4.

39 Yoshikawa T, Naito Y, Kishi A, Tomii T, Kaneko T, Iinuma $S$, et al. Role of active oxygen, lipid, peroxidation, and antioxidants in the pathogenesis of gastric mucosal injury induced by indomethacin in rats. Gut 1993; 34: 732-7.

40 Halliwell B. Protection against tissue damage in vivo by desferrioxamine: what is its mechanism of action? Free Radic Biol Med 1989; 7: 645-51.

41 Krishna MC, Graham DA, Samuni A, Mitchell JB, M Russo A. Oxoammonium cation intermediate in the nitroxide catalyzed dismutation of superoxide. Proc Natl Acad Sci USA 1992; 89: 5537-41.

42 Samuni A, Chevion M, Czapski G. Unusual copperinduced sensitization of the biological damage due to superoxide radicals. J Biol Chem 1981; 256: $12632-5$.

43 Samuni A, Aronovitch J, Godinger D, Chevion M, Czapski $\mathrm{G}$. On the cytotoxicity of vitamin $\mathrm{C}$ and metal ions. A sitespecific Fenton mechanism. Eur $\mathcal{f}$ Biochem 1983; 137: 119-24

44 Karmeli F, Eliakim R, Okon E, Rachmilewitz D. Gastric mucosal damage by ethanol is mediated by substance $P$ and prevented by ketotifen, a mast cell stabilizer. Gastroenterology 1991; 100: 1206-16. 